\title{
Rapeseed fat in dairy cow feeding
}

\author{
LIISA SYRJÄLÄ-QVIST and PENTTI ASPILA \\ Department of Animal Husbandry, University of Helsinki, SF-00710 Helsinki 71
}

\begin{abstract}
Dairy cows on silage and hay-based diets were given a barley-oats concentrate mixture containing $13 \%$ rapeseed feed in four different forms: diet 1) rapeseed meal, 2) rapeseed meal + rapeseed oil, 3) rapeseed meal + crushed rapeseed and 4) protected fatty rapeseed meal. The fat content of the rapeseed feed was: diets 2 and 3, $7.1 \%$ of dry matter; diet $4,6.3 \%$; diet $1,2.4 \%$. From the rapeseed the cows received only about $2 \mathrm{~g}$ digestible crude fat $/ \mathrm{kg} 4 \% \mathrm{FCM}$, the total fat supply on diets 2,3 and 4 being $15 \mathrm{~g}$ digestible crude fat $/ \mathrm{kg}$ $4 \%$ FCM. At so low a level, the rapeseed fat did not have any clear effect on the milk fat or milk protein contents, or on the iodine number or fatty acid composition of the milk fat. The milk yield increased, however, when the diet contained rapseed feed.
\end{abstract}

\section{Introduction}

Many studies have shown that when fats and oils are fed to ruminants they undergo modification in the rumen. The esterified fatty acids can be liberated by hydrolysis, and long-chain unsaturated fatty acids can undergo complete or partial hydrogenation, to yield stearic acid $\left(\mathrm{C}_{16}\right)$ and a wide variety of trans- and positional isomers of unsaturated fatty acids (PALMQUist and JENKINS 1980). The effect on the milk composition of addition of fat or oil to the diet has varied, however, depending on such factors as the degree of unsaturation of the fatty acids in the dietary fat.

The object of this experiment was to study the changes occurring in the milk composi- tion when cows were fed rapeseed meal, alone or together with rapeseed oil or crushed seeds. Protected fatty rapeseed meal was also used as a feed component. This experiment was intended as a pilot study for further experiments on rapeseed used as protein and energy additives for high-production dairy cows.

\section{Experimental procedures}

The experiment was performed with 8 Ayrshire cows and started when the average time elapsed from calving was 37 days. After the standardization period of 2 weeks, the animals were divided into four groups and changed to the experimental feeds during the 
2 following weeks. The test period lasted 4 weeks and the post-test period 4 weeks.

During the standardization and post-test periods, all the animals received the same feed consisting, on the average, of $3 \mathrm{~kg}$ hay, $6 \mathrm{~kg}$ silage dry matter and $7 \mathrm{~kg}$ barley-oats (1:1) concentrate, plus minerals and vitamins. In the standardization period the silage was grass silage, but in the test and post-test periods it was both grass and sugar-beet top silage. During the test period the diets were also the same, except for the composition of the concentrate mixture. It contained $13 \%$ rapeseed feed in different forms, as follows:

Group 1: rapeseed meal

Group 2: rapeseed meal + rapeseed oil

Group 3: rapeseed meal + crushed rapeseed

Group 4: protected fatty rapeseed meal

The proportions of rapeseed meal and rapeseed oil or crushed rapeseed in groups 2 and 3 were adjusted in such a way that the fat content was the same, or $7.1 \%$ of the dry matter (Tables 1-2). The fat content of the rapeseed feed in group 4 was $6.3 \%$ and in group $12.4 \%$.

The concentrate was fed individually, but the hay and silage were given group-wise. The amount of the diet was adjusted accord-
Table 2. The percentages of different feeds in the concentrate mixture during the test period.

\begin{tabular}{lrrrr}
\hline Groups & 1 & 2 & 3 & 4 \\
\hline Barley & 41.1 & 41.2 & 41.1 & 41.1 \\
Oats & 41.1 & 41.2 & 41.1 & 41.1 \\
Molasses & 1.4 & 1.3 & 1.4 & 1.4 \\
Rapeseed meal & 13.0 & 12.2 & 11.3 & - \\
Rapeseed oil & - & 0.7 & - & - \\
Crushed rapeseed & - & - & 1.7 & - \\
Protected fatty & & & & \\
rapeseed meal & - & - & - & 13.0 \\
Minerals & 3.4 & 3.4 & 3.4 & 3.4 \\
$\mathrm{~kg} / \mathrm{f} . \mathrm{u}$. & 1.30 & 1.28 & 1.28 & 1.29 \\
DCP g/f.u. & 122 & 116 & 117 & 115 \\
\hline
\end{tabular}

Group 1 = rapeseed meal

" 2 = rapeseed meal + rapeseed oil

" $3=$ rapeseed meal + crushed rapeseed

" $4=$ protected fatty rapeseed meal

ing to the nutrient requirements (SALO et al. 1982). The feeding procedures, feed sampling, analyses and calculations were as described by SyrJälä-Qvist et al. (1982). The milk was weighed on two days in every week. Milk samples were taken on two successive days for analysis at the end of the standardization, test and post-test periods. The milk samples were analysed for milk fat and protein by the infrared tech-

Table 1. The mean chemical composition and feeding value of the feeds.'

\begin{tabular}{lrrrrrrrr}
\hline & Hay & $\begin{array}{c}\text { Grass } \\
\text { silage }\end{array}$ & $\begin{array}{r}\text { Sugar- } \\
\text { beet top } \\
\text { silage }\end{array}$ & Barley & Oats & $\begin{array}{r}\text { Rape- } \\
\text { seed } \\
\text { meal }\end{array}$ & $\begin{array}{r}\text { Crushed } \\
\text { rapeseed }\end{array}$ & $\begin{array}{c}\text { Protected } \\
\text { fatty } \\
\text { rapeseed } \\
\text { meal }\end{array}$ \\
\hline Dry matter, \% & 84.5 & 26.7 & 16.4 & 74.0 & 77.4 & 88.8 & 92.5 & 89.5 \\
\% of DM & & & & & & & & \\
Ash & 7.1 & 6.8 & 20.8 & 2.8 & 3.4 & 7.8 & 4.5 & 7.8 \\
Crude protein & 10.7 & 15.0 & 15.0 & 10.7 & 12.6 & 38.2 & 22.1 & 36.3 \\
Crude fat & 2.5 & 5.4 & 5.0 & 2.2 & 5.6 & 2.4 & 43.6 & 6.3 \\
Crude fibre & 30.5 & 29.2 & 17.7 & 5.7 & 10.7 & 13.8 & 7.3 & 14.0 \\
N-free extract & 49.2 & 43.6 & 41.5 & 78.6 & 67.7 & 37.8 & 22.5 & 35.6 \\
DM kg/f.u. & 1.58 & 1.34 & 1.36 & 0.88 & 1.03 & 1.14 & 0.55 & 1.12 \\
DCP g/f.u. & 118 & 145 & 164 & 70 & 101 & 361 & 108 & 305 \\
\hline
\end{tabular}

$\mathrm{DM}=$ Dry matter

DCP $=$ Digestible crude protein

f.u. $=$ feed unit $=0.7$ starch equivalent

1 The feeding values were calculated using the digestibility coefficients and values presented by SALO et al. (1982). 
nique, for the iodine number by the Hanus method (see KAUFMANN 1958) and for fatty acids as described by ANTILA and KanKare (1983).

\section{Results and discussion}

The $4 \%$ fat corrected milk (FCM) yield improved in every group during the test period and decreased again during the post-test period (Table 3). The average increase from the standardization period to the test period in groups 1, 2, 3 and 4 was 1.1, 5.6, 1.0 and $1.4 \mathrm{~kg}$, respectively. The milk fat and milk protein content also tended to increase during the test period, but not significantly $(P>0.05)$. In all the groups the rapeseed feeds had some effect on the milk fat composition. The iodine number of the milk fat was lower in the test period than in the standardization and post-test periods, the deviation in groups 1, 2, 3 and 4 averaging $3.5,3.5,2.5$ and 2.0 units, respectively (Table 3). There were no significant differences between the groups $(\mathrm{P}>0.05)$.
The clearest change in the fatty acid composition on the milk fat was in the proportion of oleic acid $\left(\mathrm{C}_{18: 1}\right)$; it decreased in all the groups in the test period and remained at a similary low level in the post-test period. The proportion of linolic acid $\left(\mathrm{C}_{18: 2}\right)$ also decreased in the test period in all the groups, but that of linoleic acid $\left(\mathrm{C}_{18: 3}\right)$ was fairly constant throughout the experiment. The proportion of the total $\mathrm{C}_{18}$-unsaturated fatty acids in groups 1, 2, 3 and 4 in the test period was on average $4.9,4.6,5.9$ and $2.5 \%$ units lower than in the standardization and posttest periods. The differences between the groups were not significant $(P>0.05)$, the difference between groups 3 and 4 was indicative $(\mathrm{P}<0.10)$.

The rapeseed oil of varieties low in erucic acid contains, on average, $56 \%$ oleic acid $\left(\mathrm{C}_{18: 1),} 23 \%\right.$ linolic acid $\left(\mathrm{C}_{18: 2}\right)$ and $12 \%$ linoleic acid $\left(\mathrm{C}_{18: 3}\right.$ (ANON.). In spite of the high proportion of these unsaturated fatty acids, the diets containing the rapeseed fat did not significantly improve the softness of the milk fat in this experiment. The main

Table 3. The mean milk yield and composition of milk in different groups.

\begin{tabular}{|c|c|c|c|c|c|c|c|c|c|c|c|c|}
\hline \multirow{2}{*}{$\begin{array}{l}\text { Periods } \\
\text { Groups }\end{array}$} & \multicolumn{4}{|c|}{ Standardization } & \multicolumn{4}{|c|}{ Test } & \multicolumn{4}{|c|}{ Post-test } \\
\hline & 1 & 2 & 3 & 4 & 1 & 2 & 3 & 4 & 1 & 2 & 3 & 4 \\
\hline $\mathrm{FCM}, \mathrm{kg} / \mathrm{d}$ & 25.9 & 26.6 & 25.3 & 27.9 & 27.0 & 32.2 & 26.3 & 29.3 & 24.8 & 26.2 & 25.6 & 24.8 \\
\hline Milk fat $\%$ & 4.3 & 4.2 & 4.7 & 4.4 & 4.4 & 4.8 & 4.6 & 4.7 & 4.8 & 4.4 & 4.8 & 4.5 \\
\hline Milk protein \% & 2.8 & 2.7 & 2.7 & 2.9 & 3.0 & 3.1 & 3.0 & 3.0 & 3.0 & 3.0 & 3.0 & 3.2 \\
\hline Iodine number & 32.5 & 33.1 & 38.0 & 31.1 & 28.6 & 30.6 & 34.4 & 29.1 & 31.8 & 35.2 & 35.8 & 31.2 \\
\hline \multicolumn{13}{|l|}{$\begin{array}{l}\text { Fatty acids } \% \\
\text { in milk fat }\end{array}$} \\
\hline $\mathrm{C}_{10}$ & 1.9 & 2.2 & 1.8 & 2.0 & 3.2 & 3.0 & 3.2 & 3.0 & 2.8 & 2.7 & 3.0 & 2.8 \\
\hline $\mathrm{C}_{12}$ & 2.3 & 2.5 & 2.0 & 2.4 & 3.8 & 3.6 & 3.9 & 3.6 & 3.6 & 3.6 & 4.0 & 3.8 \\
\hline $\mathrm{C}_{14}$ & 9.9 & 10.2 & 8.7 & 10.5 & 12.4 & 12.2 & 12.4 & 12.2 & 12.4 & 12.2 & 12.4 & 12.6 \\
\hline$C_{16}$ & 33.2 & 31.1 & 28.8 & 34.7 & 35.6 & 34.2 & 32.4 & 35.6 & 32.4 & 36.1 & 33.9 & 37.8 \\
\hline $\mathrm{C}_{18}$ & 11.4 & 11.4 & 11.6 & 11.0 & 10.2 & 11.4 & 11.1 & 11.0 & 8.9 & 9.6 & 10.0 & 10.2 \\
\hline$C_{18: 1}$ & 28.0 & 28.7 & 33.6 & 26.1 & 18.6 & 20.3 & 22.3 & 19.7 & 18.8 & 20.9 & 22.5 & 18.6 \\
\hline$C_{18: 2}$ & 2.2 & 2.0 & 2.2 & 2.0 & 1.8 & 1.8 & 1.8 & 1.9 & 1.6 & 1.8 & 1.8 & 1.6 \\
\hline$C_{18: 3}$ & 0.8 & 0.7 & 0.8 & 0.7 & 0.8 & 0.7 & 0.8 & 0.8 & 0.6 & 0.8 & 0.7 & 0.7 \\
\hline $\begin{array}{l}\text { total } C_{18^{*}} \\
\text { unsaturated }\end{array}$ & 310 & 314 & 36.6 & 28.8 & 212 & 228 & 24.9 & 234 & 211 & 235 & 250 & 0 \\
\hline
\end{tabular}

Group 1 = rapeseed meal

$" \quad 2=$ rapeseed meal + rapeseed oil
$" \quad 3=$ rapeseed meal + crushed rapeseed
$" \quad 4=$ protected fatty rapeseed meal 
reason is probably that the animals received only small amounts of rapeseed fat. The total daily supply of crude fat on diets 2, 3 and 4 averaged $572 \mathrm{~g} / \mathrm{cow}$, rapeseed fat contributing about $11 \%$, or $62 \mathrm{~g} /$ cow. According to the digestibility coefficients presented in feed tables (SALo et al. 1982), the animal received $15 \mathrm{~g}$ digestible crude fat per $\mathrm{kg}$ FCM, the contribution of rapeseed being only $2 \mathrm{~g} / \mathrm{kg}$ FCM.

FrANK (1978) found that the iodine number of the milk fat was clearly higher when the animals received a diet containing $8.4 \%$ crushed rapeseed in the concentrate mixture

\section{Reference}

ANON. Kevătőljykasvien tuotanto. Tieto tuottamaan 8: 1-72. Maatalouskeskusten Liiton julk. no. 630.

AntILA, V. \& KanKare, V. 1983. The fatty acid composition of milk lipids. Milchwissenschaft 38: 478-481.

Armstrong, D.G. \& Prescott, J.H.D. 1971. Amount, physical form and composition of feed and milk secretion in the dairy cow. Lactation p. 349-377 ed. I.R. Falconer, Butterworths, London.

Brooks, C.C., Garner, G.B., Gehrke, C.W., Muhrer, M.E. \& Phander, W.H. 1954. The effect of added fat on the digestion of cellulose and protein by ovine rumen microorganisms. J. Anim. Sci. 13: 758-764.

FrANK, B. 1978. Rapeseed as a source of fat for dairy cows. Proc. 5th Int. Rapeseed Conf. 2: 213-216, Malmö, Sweden. than when they were on a diet of rapeseed meal. The amount of digestible crude fat that the animals received in the rapeseed was, however, $10 \mathrm{~g} / \mathrm{kg} \mathrm{FCM}$, the total amount being $25-28 \mathrm{~g}$.

The effect of fat and oil additives on milk production and the milk fat composition has varied from study to study (ARMSTRONG and PRESCOTT 1971). The reasons have probably been differences in the fat content of the basic feeds and in the effect of the fat on the digestibility of the other components (BROOKS et al. 1954, PalmQuist and Jenkins 1980).

Kaufmann, H.P. 1958. Analyse der Fette und Fettprodukte. 1. 1104 p. Berlin.

Palmquist, D.L. \& Jenkins, T.C. 1980. Fat in lactation rations: review. J. Dairy Sci 63: 1-14.

SAlo, M.-L., TuORI, M. \& KiISKINEN, T. 1982. Rehutaulukot ja ruokintanormit. 70 p. Helsinki.

Syrjälä-Qvist, L., Tuori, M. \& SetĀlä, J. 1982. Rapeseed meal as a protein source for high-production dairy cows on grass silage - and hay-based feeding. J. Scient. Agric. Soc. Finl. 50: 155-165.

Ms received March 20, 1984 


\section{SELOSTUS}

\section{Rypsirasvan vaikutus maidon koostumukseen}

\section{Liisa Syrjälä-Qvist and Pentti Aspila}

Helsingin yliopiston kotielaintieteen laitos, 00710 Helsinki 71

Pienimuotoisessa ja vain suuntaa antavaksi tarkoitetussa kokeessa selvitettiin rypsin rasvan vaikutusta maidontuotannossa. Săilörehu- ja heinăruokinnalla olevien lehmien ohra-kaura-văkirehuseokseen lisăttiin eri dieeteissă rypsirehua seuraavasti: 1) tavallista rypsirouhetta, 2) tavallista rypsirouhetta + rypsiöljyä, 3) tavallista rypsirouhetta + rikottuja siemeniä ja 4) suojattua rasvaista rypsirouhetta. Rypsirehun rasvapitoisuus oli dieeteissă 2 ja $37.1 \%$, dieetissä $46.3 \%$ sekă tavallisessa rouheessa $2.4 \%$ kuiva-aineesta. Kutakin rypsirehua kăytettiin văkirehuseoksessa $13 \%$.
Kaikilla rypsirehuilla oli selvă positiivinen vaikutus maidontuotantoon. Maidon rasva- ja valkuaispitoisuuteen, sekä maitorasvan jodilukuun ja rasvahappokoostumukseen sen sijaan ei rypsirehuilla ollut selvăă vaikutusta. Syynä lienee osaltaan se, että rypsirehujen rasvapitoisuus jäi suhteellisen alhaiseksi. Lehmät saivat dieeteillä 2, 3 ja 4 rypsirasvaa sulavana raakarasvana vain 2 $\mathrm{g} / \mathrm{kg} 4 \%$ :ista maitoa, kokonaisrasvamäărän ollessa vastaavasti $15 \mathrm{~g}$ sulavaa raakarasvaa/ $\mathrm{kg}$ maitoa. 